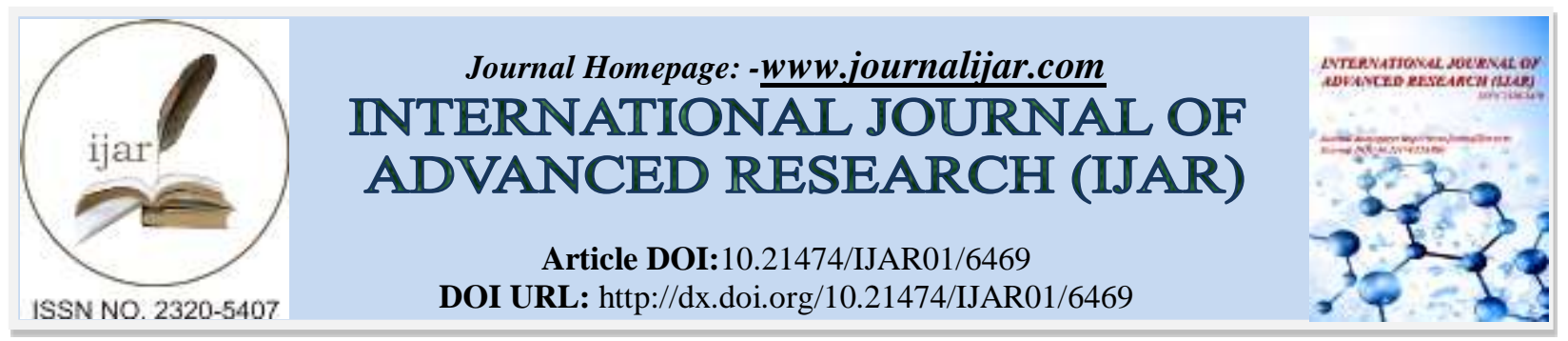

RESEARCH ARTICLE

\title{
REPRESENTATIONS OF AMERICAN FOREIGN POLICY IN CONTEMPORARY HISTORICAL AMERICAN FICTION.
}

Nisreen Tawfiq Yousef.

\section{Manuscript Info}

(.........................

Manuscript History

Received: 08 December 2017

Final Accepted: 10 January 2018

Published: February 2018

\section{Keywords:-}

The Crusades, American Foreign Policy, Richard the Lionheart, The relationship between Muslim-majority countries and the West, Historical Fiction, Historical analogy.

\section{Abstract}

This paper investigates representations of American foreign policy in contemporary American historical fiction of the Third Crusade. In this paper, I argue that in his novel The Swords of Faith (2010), Richard Warren Field deploys the analogy of the Third Crusade to reflect on the current American foreign policy. I maintain that Field creates historical parallels between Richard the Lionheart's foreign policies towards the East in the medieval times and those of the United States in our modern times since the Cold War. Through presenting Richard as frequently deploying religious, moral and humanitarian and self-defence discourses to justify his military interference in other countries' affairs without exposing his real motivations, Field, by means of historical analogy, constructs America's contemporary foreign policy as a continuation to a long history of overseas interference where the American administrations never state to the public the real intentions behind their interventionist acts. I contend that ultimately, Field tries to urge for more public awareness of American foreign relationships with other countries.

Copy Right, IJAR, 2018,. All rights reserved.

\section{Introduction:-}

Field was born in New York and graduated with a Bachelor of Arts in Music and Political Science in 1976. He is a musician and a writer. His novel The Swords of Faith won a Bronze Medal at the 2011 Independent Publisher Book Awards in the Historical Novel/Military category ${ }^{1}$. He has also written three other novels: The first one is, The Election (1997), which tackles political issues in the United States including the Electoral College system in the United States, the war on drugs, and the free market system. The second novel is, Dying to Heal (2011), which Field wrote as a co-author. The novel deals with the health care system in the United States. It is co-written with Dr. Alan Fluger D.C. The third is his recently published novel The Sultan and Khan (2015), which is the sequel to The Swords of Faith. The novel narrates the story of the Mongol invasion of Baghdad in 1258, following the Crusades to the East ("About-Short Bio").

\section{Synopsis:-}

By redescribing the world of Saladin and Richard, Field's The Swords of Faith provides the modern reader with the Islamic-Western clash during the Third Crusade and reflects on more pressing issues of the historical present in the

\footnotetext{
${ }^{1}$ This was announced on the Independent Publisher Website: "2011 Independent Published Book Wards Result Announcement."
} 
past and in the future. In the novel, Saladin endeavours to protect the Islamicate region threatened by the Crusaders. The novel creates an historical analogy with the Third Crusade, recontextualizing present-day discussion about Islam and the west. In addition to the clash taking place between Muslim warriors under the command of Saladin and the Crusaders under the leadership of King Richard, a solid friendship grows in the subplot of the novel between the Muslim and Arab trader Rashid and the Christian Crusader Pierre. This alliance between the two characters is repeatedly attacked by both Muslim and Christian characters. Although both characters are keen to establish peaceful relations between the opposing sides, their efforts are in vain. Pierre's son, Dawoud, grows up among Muslims in the Holy Land and never feels secure until he willingly converts to Islam. The novel ends at a point where Muslims and Western Christians are incapable of achieving ultimate peace.

Through an analysis of American foreign policy after World War II, in his book The Ruses for War: American Interventionism since World War II (2007), John Quigley argues that since the Cold War, the successive American administrations have been deploying a unified pattern on interference: American interventionism has been always clandestinely conducted as the true agendas have never been stated by the government to the public (377). For him, since the World War II, American presidents do not always provide the public with the true causes of a military action; rather, they omit or exaggerate in order to convince the public of the validity of their use of force. ${ }^{2}$ He maintains that domestic political concerns may be the main reason behind interventionism; yet, it is unlikely that a president state them (15). Based on my reading of Field's novel, I contend that Field seems to share Quigley's notions about contemporary American foreign policy. Field, I argue, establishes an historical analogy between Richard's foreign policy and that of America's post-Cold. By means of historical parallel, Field constructs contemporary American policy as a series of a long history of interventionism where the real purposes are not stated to the public. Field shows Richard as often using, in addition to religious pretexts, different discourses to present his interventionist acts as motivated by humanitarian and self-defence causes without stating his real intentions to his people and army.

Richard's interventionist tendency is manifested in his invasion of Cyprus as we see in the novel. Historically speaking, according to the historian Richard of Devizes, the reason behind Richard's invasion of Cyprus was that on their way to Syria, some of the English ships broke up on the seaport of the city. The Cypriots killed many of those on the ship and some were captured including Berengaria, the future Queen of England, and Issac, the ruler of Cyprus acquired a substantial portion of the spoils. On hearing that, Richard commanded his army to attack the city: many Cypriots were killed, spoils were seized and the Prince was captured (35-37). As the historian James Reston points out, Issac was on good terms with Saladin (141). Yet, Reston still mentions Isaac's attack on the wrecked English ships as the direct primary reason for Richard's conquest of the city (140)

In the novel, presenting Richard's assault on Cyprus, Field remains true to the historical chronicles. He presents the real reason behind the attack is that a number of the English ships have wrecked on the shores of Cyprus (238-239). In light of this, I suggest that Field makes use of this historical incident to suggest that Richard exploits situations to justify his acts of interference without stating his real intentions to the public. In Field's The Swords of Faith, Richard exploits the situations for his own imperialist plans: "We will turn this storm into our blessings" (239). Though Richard is advised to be patient and to consider negotiating with Isaac rather than using armed force, he rejects the advice and insists on conducting a military action against the Cypriots (243). As a result of his attack on Cyprus, Richard turns Issac into an ally and establishes with him a business: "This emperor will do business with me, for this island" (247).

During his alleged mission of protecting the Holy Land, Richard decides to visit his married sister, whom, as he claims, has been treated unfairly by Tancred, King of Sicily. While Richard justifies his visit to the Island by a moral and humanitarian obligation, this visit turns out to have economic dimensions as Tancred and Richard eventually have a business agreement on the Island (209-212). Thus, while he is supposed to be committed to his religious mission in the Holy Land, Richard appears as indulged in fulfiling materialist objectives. This ultimately suggests that Richard exploits situations and circumstances to justify his interference with the affairs of other lands and to direct them to his own economic and political interests without stating his real intentions to the public.

2 Quigley's argument is based on a study of American interventionism in Korea, Indonesia, Lebanon, Cuba, Vietnam, the Congo, the Dominican Republic, Cambodia, Angola, Shaba, Iran, Nicaragua, El Salvador, Lebanon, Grenada, Libya, the Philippines, Panama, Liberia, Iraq, Somalia, Sudan, Kosovo, and Afghanistan. 
In spite of their apparent united cause, Richard and Philip, King of France, are also pictured as irreconcilable rivals competing with one another for land. Philip and Tancred, the Sicilian King also conspire against Richard ${ }^{3}$ (224). In addition, Philip withdraws his forces from the Holy Land leaving Richard's troops unaided, which is historically evident: "Philip will be seen as a deserter.... He is the one leaving an important task undone" (293). Consequently, after agreeing a peace truce with Saladin, Richard demands that all the French troops who have not supported him with the sufficient sacrifice not to be given permits for pilgrimage to Jerusalem: "The English King does not wish to grant passports to the Christians from France who failed to assist in his efforts here. He asks that the Sultan support these wishes" (482). Such demands by Richard underscore the political competition of the alleged holy mission as he does not seem to be eager to fulfil one of the chief supposed targets of the Crusading campaign. Reading the novel within our contemporary context, I argue that Field tries to establish an historical analogy between the stance of the French troops on supporting Richard's forces and the contemporary position of France on the "War on Terror". On Wednesday, January 22, 2003, France and Germany declared that they were planning to coordinate their disapproval to war in Iraq. The French president Jacques Chirac and the German chancellor Gerhard Schroder believed that a decision on military action should be taken by the UN, depending on the findings provided by the weapons inspectors. For both of them, war is "the worst of solutions" ("France and Germany Unite against Iraq War"). Nonetheless, France's stand of the "War on Terror" provoked criticism from the American side. Commenting on France's decision regarding America's war against terrorism, Kenneth R. Timmerman argues that by opposing the "War on Terror", France has betrayed the United States (1). He maintains that in an attempt to show how isolated the United States was in its decision, a week after the war, the French media coverage tried to focus on anti-war protesters around the globe including the United States (2). Timmerman goes on to argue that the commentators of the French media presented the Anglo-American war as an act of aggression that led to the death of many civilians (2). As Colum Lynch and Peter Behr point out, the US was planning to assign a senior American executive to supervise the exploration and production of Iraqi oil. They maintain, should the war in Iraq proved to be successful, the United States might claim the right to manage selling Iraqi oil for the benefit of the nation. Nevertheless, they draw attention to that while the United States was planning to oversee Iraqi oil, France was concerned at protecting its interests in developing Iraqi oil in the future. Accordingly, I suggest that Field establishes an historical parallel between Richard's actions in the Holy Land and contemporary American foreign policy with regard to the "War on Terror" in Iraq. Richard seems to be concerned about keeping his interests and political supremacy in the Holy Land while at the same time is concerned about undermining the French influence in Jerusalem. For him the French army has not contributed sufficiently towards this Crusade and therefore should not benefit from its outcomes. Parallel to this situation, the United States was critical of that France refused to take part in the "War on Terror". While France was concerned about protecting its interests in Iraq, the United States was keen to maintain its political dominance and economic interests in the country.

Repeatedly in the sub-plot Field's The Swords of Faith makes reference weapons and weapon inspections (234-237). Pierre and the Christian villagers keep arms in hiding. They justify possessing these crossbows and arm by indicating that they need them to defend themselves against the assault of the bandits who carry out regular attacks on their village (237). In order to maintain his political and economic dominance over the village, the Muslim emir does not approve the villagers' possession of weapons, particularly after he receives information about hidden arms in the village (236). ${ }^{4}$ The existence of these weapons is used by the emir to justify his intervention in the village. I suggest that these representations are designed to trigger realization of parallels between the Third Crusade and contemporary "War on Terror", though the situation is the novel is converted, as it is the Christians are who are hiding the arms while it is the Muslims who disapproves it, Field alludes to Iraq's weapons of mass destruction issue and thereby highlights the different discourse the United States has utilized to justify its political and military interference. In an interview Paul Wolfowitz, American deputy secretary of defence was asked about the connection between the 9/11 attacks and the War on Terror. Wolfowitz argued that Iraq's acquisition of mass destruction was the primary reason for a military action in Iraq. However, as Quigley argues, Iraq was depicted as a serious threat to the stability in the Middle East region due to its possession of weapons of mass destruction. Yet, such claims were refuted as Hans Blix, the head of the UN inspection team in Iraq, informed the Security Council that they found no biological laboratories in Iraq (369-370). For him, as the American forces in Iraq did not find chemical, biological or

\footnotetext{
${ }^{3}$ Philp sends a letter Tancred in which he describes Richard as "treacherous and untrustworthy". The latter offers an alliance between Philp and Tancred that aims to destroy Richard's forces (242).

${ }^{4}$ In The Swords of Faith, this emir shows profound interest in possessing political power in the Holy Land and is always contradicted by Saladin. He is critical of that Saladin is tolerant and merciful to Christians (77-78).
} 
nuclear weapons, Bush rushed to announce his intentions of overthrowing Saddam Hussein's regime. As he points out, some viewed this act as a support for Israel while others perceived it as a means of controlling oil in Iraq (375).

Representations of the Massacre of Acre in the novel, I suggest, are highly significant in this respect as they are meant to create yet an historical analogy between the Third Crusade the modern Euro-American war in Afghanistan. As indicated in the novel, Richard demands the handover of the Christian captives and refuses to negotiate with Saladin. When Saladin fails to send the required amount of gold and to hand the poisoners over to Richard, the latter decides to carry out the execution of thousands of Muslim captives (301). This reminds us of that after the 9/11 attacks, the United States demanded the Taliban government's extradition of bin Laden, For Quigley, this stance question Bush's statement that the Taliban's refusal to extradite bin Laden was a cause for the invasion of Afghanistan (360-361). ${ }^{1}$ As John F. Burns and Christopher S. Wren in their article "Without Evidence, the Taliban Refuses to Turn Over bin Laden" pointed out, the Taliban's ambassador to Pakistan, mullah Abdul Salam Zaeef that the United states has to provide evidence of bin Laden's involvement in the 9/11 attacks. Only in this case, the Taliban government is ready to trial bin laden. However, Bush stated that the handover of bin Laden and his network are not open for negotiations and discussion.

In the novel, after signing the agreement, Richard promises to retake Jerusalem (488). He points out: "this agreement is a truce", indicating that the settlement between him and Muslims is only provisional and that another military action is likely to take place in the future. Furthermore, after his return to Europe, Richard decides to retake his reclaim all the French lands and the castles that have been captured during his absence: "It's only a matter of time before we take the place. This is an easy one" (504). This declared policy indicates an obvious which continuity in Richard's interventionist activities whatever his justification might be. In view of this, I suggest that Field presents the American foreign policy as a long series of interventionism in other states affairs where an administration does not provide the public with the actual agendas for the use of force, which suggests that the actual reasons of war remained publicly unstated, as suggested by Quigley.

\section{Conclusion:-}

As I have argued in this article, Field deploys the historical analogy of the Third Crusade to reflect on the American foreign policy since the Cold War. Filed, I contend, tries to create historical parallels between Richard the Lionheart's foreign policies in the medieval times and those of the United Sates in our present times. By creating such similarities, Field tries to construct American foreign policy as a series of political and military interference where the real agendas are not declared. Thus, Field's novel can be seen as a call for more Western public awareness of American international affairs towards other countries.

\section{Works Cited:-}

1. “About-Short Bio." Richard Warren Field's Blog. Word Press, n.d. Web. $21 \quad$ Jan. 2015. <http://www.richardwarrenfield.com/About\%20-\%20Short\%20Bio.html $>$.

2. Burns, John F. and Christopher S. Wren. "Saudi Arabia Cuts Ties with Taliban." ntimes. The New York Times. 26 Sep. 2001. Web. 22 Jun. 2018

<http://www.nytimes.com/learning/teachers/featured_articles/20010926wednesday.html.

3. Devizes, Richard. The Chronicles of Richard Devizes of the Time of King Richard the First. Ed. John. T Appleby. London: Thomas Nelson and Sons Ltd. Print.

4. Field, Richard Warren. The Swords of Faith. United States: Strider Nolan Media, Inc, $2010 . \quad$ Print.

5. "France and Germany Unite against Iraq War." The Guardian. World News, 22 Jan. 2003. 5 Jan. 2018. Web.<https://www.theguardian.com/world/2003/jan/22/germany.france >.

6. Lynch, Colum and Peter Behr." US, Allies Clash Over Plan.” Global Policy. Washington Post. 3 April 2003. Web. 5 Jan. $2018<$ https://owl.english.purdue.edu/owl/resource/747/08/>.

7. Quigley, John B. The Ruses for War: American Interventionism since World War II. New York: Prometheus Books, 2007. Print.

8. Reston, James. Warrior of God: Richard the Lionheart and Saladin in the Third Crusade. New York: Doubleday, 2001. Print.

9. Timmerman, Kenneth R. The French Betrayal of America. New York: Crown Forum, 2004. Print.

10. Wolfowitz, Paul. Interview by Tannenhaus. "Vanity Fair." archive.defense.gov. U.S. Department of Defense, 9 May 2003. Web. 2 Jul. 2017 〈http://archive.defense.gov/Transcripts/Transcript.aspx?TranscriptID=2594>. 